\title{
Child Height Development in the Past Half Century in North East Asia: Animal Protein and Other Essential Nutrients
}

\author{
Hiroshi Mori* \\ Professor Emeritus, Senshu University, Japan \\ *Corresponding author: Hiroshi Mori, Professor Emeritus, Senshu University, Chiyoda-ku, Tokyo, Japan \\ To Cite This Article: Hiroshi Mori, Child Height Development in the Past Half Century in North East Asia: Animal Protein and Other Essential \\ Nutrients. Am J Biomed Sci \& Res. 2021 - 11(5). AJBSR.MS.ID.001676. DOI: 10.34297/AJBSR.2021.11.001676.
}

Received: 阱 January 01, 2021; Published: 眥 February 01, 2021

\begin{abstract}
Economies in North-East Asia made rapid progress after WW II. Japan was the first-runner, followed by South Korea with some two-decade-lag due to the Korean War (1950-53). As the standard of living, food supply in particular, improved, children grew taller in height unprecedentedly, by more than $10 \mathrm{~cm}$ in a half-century. Male teens in Japan were $2-3 \mathrm{~cm}$ taller in mean height than their Korean peers in the 1960-70s but ceased to grow any taller in the early-1990s, whereas Korean teens kept growing taller vigorously, to overtake their Japanese peers by $3 \mathrm{~cm}$ in the mid-2000s and then ceased to grow taller afterwards. Economy in South Korea has kept very prosperous toward the end of the 2010s and supply of animal-sourced foods kept increasing steadily. When growth patterns of boys' height from 1st graders in primary school to seniors in high school examined for the two countries, velocity began to decline steadily in South Korea in the early-2000s, to be appreciably slower than their Japanese peers toward the end of the 2010s. As pre-school boys in South Korea were significantly taller than their Japanese peers in the mid-2000s, Korean teens were still taller than their Japanese peers in the end of the 2010s, but it could be predicted that the height advantage of Korean teens over their Japanese peers would not last in the future decades.

Children in Japan ceased to grow taller in height in the 1990s, because they started to turn away from fruit at-home consumption a decade ago in the late-1970s. Younger cohorts in South Korea started to steer away from vegetables at their household consumption drastically in the mid-1990s. It is suspected that a drastic reduction in vegetable consumption by growing children and pregnant mothers may have resulted in slower growth in child height, as observed in South Korea since the early-2000s.
\end{abstract}

Keywords: Child height, Growth velocity, South Korea, Japan, Vegetables and fruit

Stature is a net measure that captures the supply of inputs to health (Steckel, 1995) [1].

\section{Introduction}

People in North-East Asia are distinctly different from those in North-Central Europe, Africa, and Mid-East Asia in respect of head structure, hair/eye color and complexion: racial features. People in China, Korea and Japan may not be the same, different by place they live in the country, living standard they take by place and periods, but can be assumed similar in genetical endowments, although individuals differ significantly. Compared by age, schoolboys in Japan were appreciably taller than their Korean peers in the earlier years, the 1960s through the mid-1980s. In respect of per capita
GDP, Japan was significantly wealthier than South Korea (table 1) and per capita supply of animal sourced foods was much greater in Japan than in S. Korea then (table 2). As people's living standards improved, children began to grow taller in height in North East Asian countries. But people can't be Giraffe. Similarly, Asians can't be Caucasians in hair color or head structure but could be close to Caucasians in stature, if "the supply of inputs to health" were adequate in the long-run (tables 1,2 and 3). 
Table 1: Changes in per capita real GDP, Japan and South Korea, 1970 to 2017.

\begin{tabular}{|c|c|c|c|c|c|c|c|c|c|c|c|}
\hline & 1970 & 1975 & 1980 & 1985 & 1990 & 1995 & 2000 & 2005 & 2010 & 2015 & 2017 \\
\hline Japan & 11876 & 14371 & 18981 & 18415 & 26780 & 32588 & 34571 & 36244 & 36596 & 38875 & 40374 \\
\hline S. Korea & 1972 & 4007 & 4831 & 6630 & 12327 & 20037 & 21825 & 27723 & 31590 & 34411 & 36265 \\
\hline
\end{tabular}

Sources: Oxford University, Our World in Data.

Table 2: Changes in mean height of schoolboys by age, South Korea and Japan, 1970 to 2017.

\begin{tabular}{|c|c|c|c|c|c|c|c|c|c|c|c|}
\hline S. Korea & \multicolumn{11}{|c|}{ (cm) } \\
\hline & 1970 & 1975 & 1980 & 1985 & 1990 & 1995 & 2000 & 2005 & 2010 & 2015 & 2017 \\
\hline 6 years & 112.9 & 112.9 & 115.4 & 116.2 & 117.7 & 119.0 & 120.2 & 121.0 & 121.8 & 120.5 & 120.6 \\
\hline 12 years & 143.7 & 143.2 & 145.2 & 147.6 & 149.7 & 152.0 & 154.8 & 156.9 & 158.0 & 156.7 & 157.2 \\
\hline 17 years & 166.1 & 166.0 & 167.3 & 168.9 & 169.7 & 171.0 & 172.9 & 173.7 & 173.7 & 173.4 & 173.5 \\
\hline Japan & & & & & & & & & & & \\
\hline 6 years & 114.5 & 115.2 & 115.7 & 116.4 & 116.8 & 116.8 & 116.7 & 116.7 & 116.7 & 116.5 & 116.5 \\
\hline 12 years & 147.0 & 148.6 & 149.5 & 150.1 & 151.5 & 152.0 & 152.8 & 152.6 & 152.4 & 152.6 & 152.7 \\
\hline 17 years & 167.9 & 168.8 & 169.6 & 170.2 & 170.5 & 170.9 & 170.9 & 170.8 & 170.7 & 170.7 & 170.6 \\
\hline
\end{tabular}

Sources: School Health Surveys, Dept. Education, respective country.

Note 3: year moving average, as 2000=average (1999:2001)

Table 3: Changes in per capita caloric intakes: all foods and animal products, Japan and S. Korea; 1970.

\begin{tabular}{|c|c|c|c|c|}
\hline \multicolumn{2}{|c|}{ 1970 to 2015 } & \multicolumn{2}{c|}{ Ancal/capita/day) } \\
\hline & Grand Total & Jr & Jp & Kr \\
\hline Year*1 & Jp & 2812 & 425.7 & 108.3 \\
\hline 1970 & 2721 & 3097 & 474.3 & 169.7 \\
\hline 1975 & 2736 & 3046 & 539.0 & 229.7 \\
\hline 1980 & 2785 & 2982 & 577.3 & 275.3 \\
\hline 1985 & 2854 & 2990 & 618.3 & 317.3 \\
\hline 1990 & 2950 & 3021 & 624.0 & 411.3 \\
\hline 1995 & 2938 & 3090 & 600.3 & 449.0 \\
\hline 2000 & 2895 & 3104 & 577.7 & 475.0 \\
\hline 2005 & 2816 & 3279 & 549.0 & 544.7 \\
\hline 2010 & 2691 & 3341 & 548.3 & 603.3 \\
\hline
\end{tabular}

Notes: *1 3-year moving average.

Sources: FAOSTAT, Food Balance Sheets, Old and new.

Speaking of body height, there should be some potentials, if not rigidly fixed. If your male children eat properly by advices of dieticians, get adequate sleep and play sports, they will grow to be $180 \mathrm{~cm}$ tall, not by chance, in the case of average Asian couples today. A $175 \mathrm{~cm}$ in height in senior grade, high school should not be a hard goal for your sons to attain for your sons to attain. Senior high school boys have been fixed in mean height at $170.5 \mathrm{~cm}$ since the early-1990s in Japan and their Korean peers have not exceeded $173.5 \mathrm{~cm}$ in mean height since the mid-2000s. As a food economist, specialized in demand analyses, the author has been suspecting that food consumption, "the inputs to health" for growing children have been somewhat inadequate either in Japan since the early 1980s or South Korea since the mid-1990s [2-4].

\section{Data}

In the realm of human-biology, "the first 1,000 days" are critical for determining future stature [5-7]. Cole and Mori, analyzing secular trends in child height in Japan and South Korea by SITAR, concluded: "most of the increment seen in adults had already accrued by age1.5 years" [8]. Japan's national nutrition surveys publish mean height of boys and girls by age from 1 to 19 , every year since 1946. But the size of samples, 6 years old boy in 2000, 
for example, is not large (54) to allow for quite large SD (4.7 for mean height of $117.6 \mathrm{~cm}$ ) [9]. The more comprehensive health and nutrition survey was initiated in South Korea only in the year of 1998, followed by the second one in 2001 [10].

The nationwide school health surveys have been conducted by the Ministry of Education in Japan every year since 1900 and the similar nationwide surveys have been conducted by the Department of Education in South Korea, the published data of which since 1961 are available to the author [11-12]. The Korean version of school surveys cover $1^{\text {st }}$ graders in primary school, 6 years of age to seniors in high school, 17 years of age, conducted in the first month of every school year, March. The surveys are nationwide and large in sample size but year to year fluctuations are not negligibly small, when we talk about one $10^{\text {th }} \mathrm{cm}$ annual differences, we use three year moving averages for all the age groups over the entire period, like $\mathrm{H}_{\mathrm{it}}=$ average $\left(\mathrm{H}_{\mathrm{it}}-1: \mathrm{H}_{\mathrm{it}+1}\right)$, where $\mathrm{i}$ denotes age and $\mathrm{t}$ the survey year $^{(\mathrm{A})}$.

As regards food supply/consumption, national nutrition surveys provide per capita intakes of various food groups, based on 24 hour-recall surveys of selected households and individuals by age groups in recent years, but Korean version of nutrition surveys are only available for the year of 1998 for the first time and 2001 and 2005 as the second and third years [9,10]. FAOSTAT, Food Balance Sheets, the United Nations, publish per capita supply of various food groups, in terms of per capita $\mathrm{kg} / \mathrm{year}$ and per capita kcal/day, by country, every year since 1961 [13]. Ministry/ Department of Agriculture, governments of Japan and Republic of Korea, publish Food Balance Sheets, every fiscal year for more than a half century since 1960 [14,15], which will be referred, if necessary. For the sake of international comparison, FAOSTAT should be safer for consistent, unbiased references.

A. Less than half of female middle school graduates went into high school education before the 1980s in the Korean society. Mean height of female high school students during the earlier years of this study are presumed to be a couple of centimeters taller, upward biases than the national averages by age groups. This study analyzes only male students for this reason.

\section{Secular trends in hight of children in the past half century}

Japanese and South Korean schoolboys will be compared in height over the past half century from the mid-1960s to 2018, at the age of 1 st grade of primary school, $1^{\text {st }}$ grade of middle school and 3rd grade of high school, 6, 12, and 17 years of age, measured in March in Korea and April in Japan, respectively. Twelf ${ }^{\text {th }}$ of 6 years of age registered as 1st graders of primary school should be actually 7 years old at most, depending on the days of the surveys conducted. As mentioned earlier and shown in table 3, Japanese boys were taller by $2-3 \mathrm{~cm}$ than their Korean peers at all ages in the $1970 \mathrm{~s}$ to 1980 s, caught-up by the latter in the 1990s and taken over in the mid-2000s and no further changes in mean height, regardless of age groups, are observed afterwards. Korean boys became taller by $3-4 \mathrm{~cm}$ at all ages than their Japanese peers in the latest two decades (table 3).

Mean height of schoolboys 6,12,17 years of age, respectively in Japan and South Korea are plotted every year from 1962 to 2017(3year moving average, like: $1971=(1970+1971+1972) / 3)$ in (figure 1). The youngest group, $1^{\text {st }}$ graders in primary school of Korean boys first caught-up their Japanese peers in the 1980s, when their older age groups, $1^{\text {st }}$ graders in middle school and seniors in high school were still $2-3 \mathrm{~cm}$ shorter than their Japanese peers. $1^{\text {st }}$ graders in primary school in Korea started to surpass slightly their Japanese peers in the end of the 1980 s and the older groups, $1^{\text {st }}$ graders in middle school and senior graders in high school were about equal in mean height in the 1990s as their Japanese peers, who ceased to grow any taller then. Korean schoolboys at any grades kept growing taller vigorously during the 1990s and early-2000s to be $3-4 \mathrm{~cm}$ taller than their Japanese peers in the mid-2000s and then ceased to grow any taller afterward. National economy in Japan has been dull since the early 1990s but Korean economy kept very prosperous throughout the end of the 2010s (table 1). As was often the case with developed countries, Japan may have attained her racial potential in height at $170.5 \mathrm{~cm}$ in the early-1990s and South Korea at $173.5 \mathrm{~cm}$ in the mid-2000s, respectively. Very smooth lines of height growth by age over the past half century for the two countries shown in figure 1 seem to verify the above contention: i.e., racial potentials (figure1).

The author was $165 \mathrm{~cm}$ tall, when younger. He has two sons, both of whom are $175 \mathrm{~cm}$, seemingly slightly taller than their contemporaries. The author was hungry all the way from primaryschool through high school days. His sons did not eat plentiful animal-sourced foods but never experienced every day hunger. One of them has a son, college junior, $181 \mathrm{~cm}$ tall, who is substantially taller than his classmates, but apparently shorter than his college basketball players. He was a baseball player in junior-senior high schools, who ate much more foods, slightly more meat and substantially more rice than his father. This personal observation by the author may represent the current middle-class family living standards in Japan. The only difference, if any, between Japan and South Korea, may be that competition for college entrance examinations looks severer in Korea than in Japan, i.e., after-school private-class lessons are longer to require additional meals to regular supper.

As remarked above, figure 1 provides quite normal growth trends in secular height of school boys in biologically similar, well developed nations, which can be extrapolated into the near future 
years. As the economy grew and living standard improved, children grew taller in height but did not change any further, after having attained a sort of racial potentials, Japanese approximately at $170.5 \mathrm{~cm}$ and Koreans likewise at $173.5 \mathrm{~cm}$, respectively. If they eat more, they would simply gain in weight, to higher BMI ${ }^{(\mathrm{B})}$. This view may represent what most people, professional or non-professional, are conceived of the height of children either in Japan or South Korea in the recent decades.

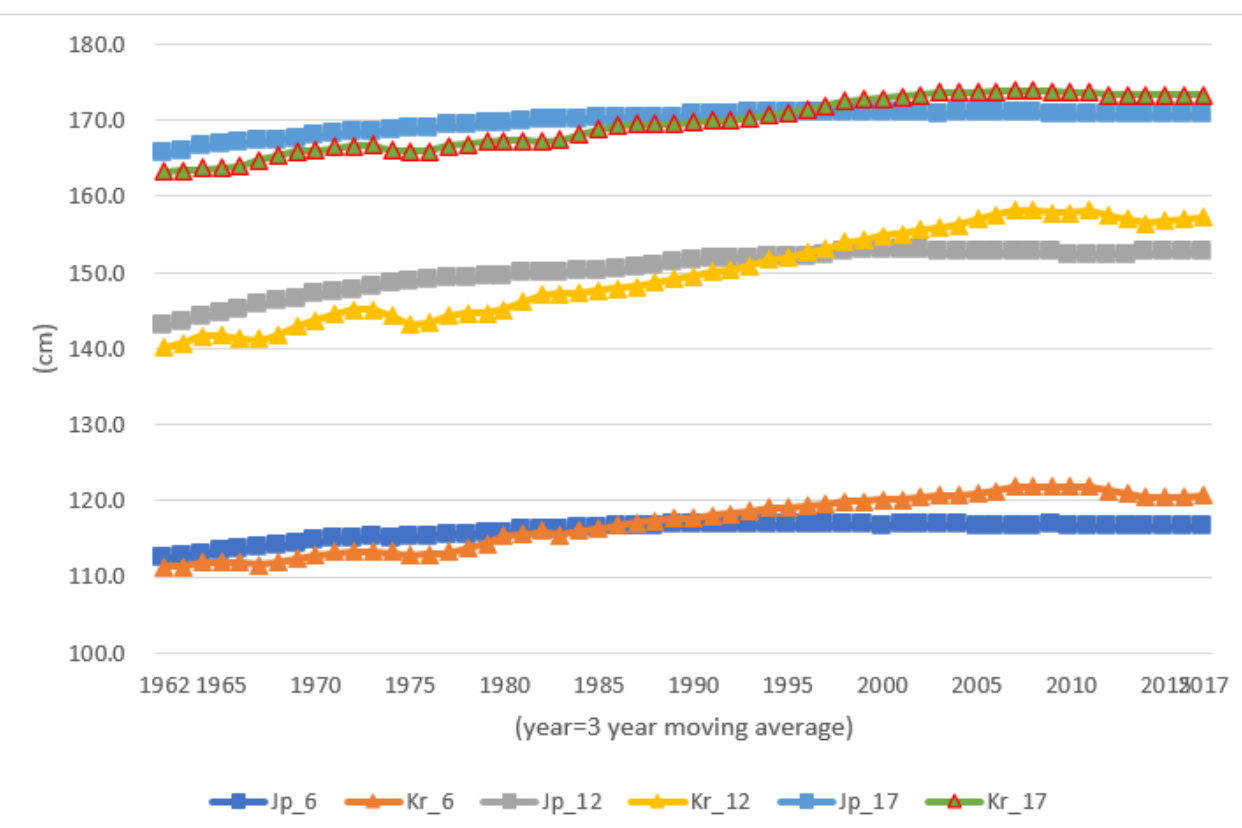

Figure 1: Changes in mean height schoolboys by age, Japan and South Korea, 1962 to 2017.

B. Changes in BMI by age groups 6, 12 and 17 years old, Japanese and Korean schoolboys from 1970 to 2018 suggest that school children both in Japan and South Korea have not increased appreciably in BMI over the survey period from 1970 to 2018 (Appendix Table 1).

\section{Changes in growth velocity in the two countries over the past few decades}

Some three years ago, the author noticed that children in Korea seemed to grow much faster in their adolescence than their Japanese peers, although the data were limited, i.e., years of observation were too few and the surveys were not uniform between the two countries. Starting a year and half ago with the larger data available, the author learnt by himself ${ }^{(c)}$ to introduce the apparatus of growth velocity into the comparative analyses of child height developments in Japan and South Korea [4,16,17].

High school seniors in 2000, for example, were born in 1983, 1 year old in 1984, primary $1^{\text {st }}$ graders, 6 years old in 1989 , middle school $1^{\text {st }}$ graders in 1995 and so on. No one grows from 6 years of age to 17 years of age instantly in the same year, say 2000. In measuring growth velocity from primary $1^{\text {st }}$ graders, 6 years of age to high school seniors, 17 years of age in any selected year, the same birth cohorts should be traced, i.e., mean height of 6 years of age in 1989 should be matched to that of 17 years of age in 2000 .
In drawing growth curves, plotting different ages observed in the same year can barely be a close proximate, or might distort the real picture [18].

Figure 2 shows changes in growth velocity from 6 to 17 years of age of Japanese and South Korean school boys, respectively from 1995 to 2017: mean height of $1^{\text {st }}$ graders in primary school in 1984 to be deducted from that of high school seniors in 1995, the same birth cohort traced. The upper left on the line of Korean boys, $55.0 \mathrm{~cm}$ in 1995 manifests the composite environmental influences the cohort born in 1978 in Korea underwent from $1^{\text {st }}$ grade in primary school in 1984 to senior grade in high school in 1995. The corresponding velocity for Japanese boys at age 17 in 1995 is $54.5 \mathrm{~cm}, 0.5 \mathrm{~cm}$ less or slower than their Korean peers. The velocity for Korean boys increased gradually to $55.5 \mathrm{~cm}$ in 2002 , whereas that for Japanese boys declined slightly to $53.9 \mathrm{~cm}$ in the same period. Japanese school boys grew by $53.9 \mathrm{~cm}$ from $1^{\text {st }}$ grade in primary school in the early-1990s to senior grade in high school in the early-2000s, $1.6 \mathrm{~cm}$ less than their Korean peers over the same period. Korean school boys, however, started to decline steadily in growth velocity to $52.1 \mathrm{~cm}$ in 2017 , whereas their Japanese peers have kept almost constant in growth velocity at $54.0 \mathrm{~cm}$ over the same period. Japanese school boys had grown by $54.0 \mathrm{~cm}$ from primary $1^{\text {st }}$ grade in 2005 to high school senior grade in 2017 , the final survey year, $1.8 \mathrm{~cm}$ greater than their Korean peers. It should 
be noted that the Korean schoolboys in high school senior grade were still $173.5 \mathrm{~cm}$ in mean height, $3 \mathrm{~cm}$ taller than their Japanese peers in the late-2010s, because preschool boys had grown taller already before the mid-2000s (figures 2,3).

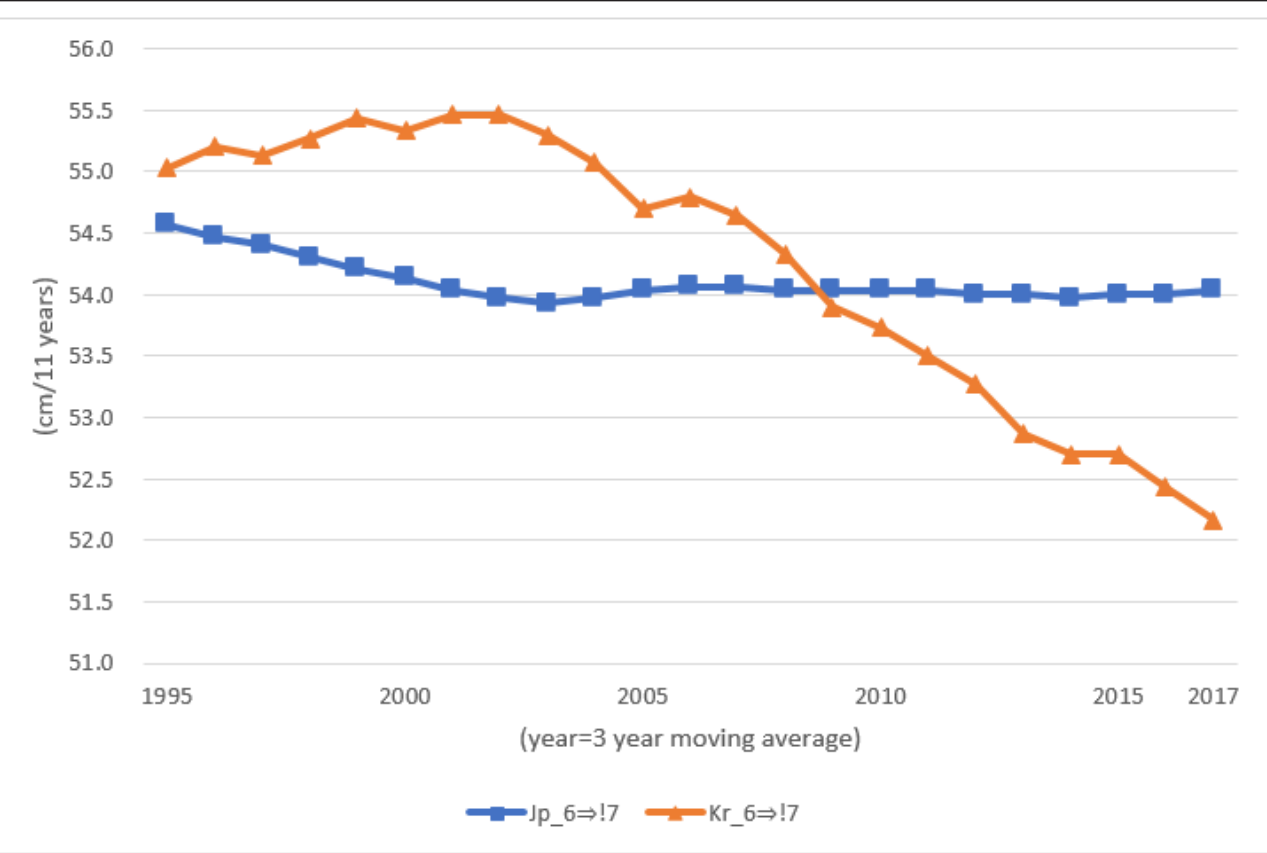

Figure 2: Changes in growth velocity from 6 to 17 years of age, Japanese and Korean schoolboys, 1995 to 2017: birth cohorts traced.

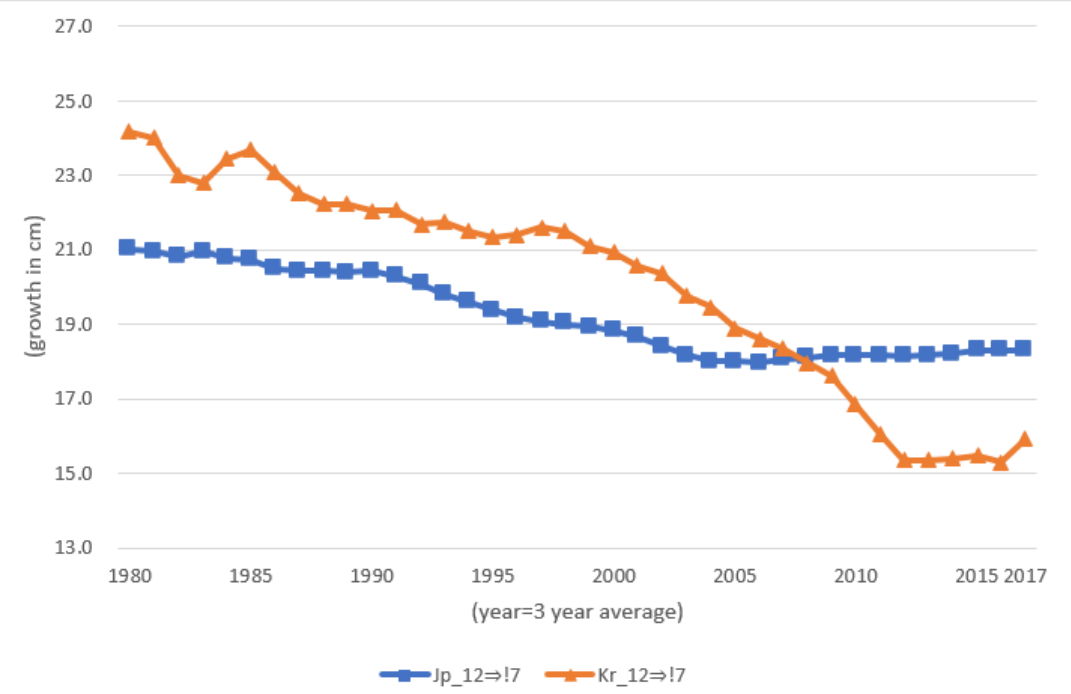

Figure 3: Changes in growth velocity from 12 to 17 years of age, Japanese and Korean schoolboys, 1980 to 2017: birth cohorts traced.

As mentioned earlier, children in Korea seem to grow faster in adolescence than their Japanese peers. With the presence of nationwide, consistent data, figure 3 is constructed to ascertain the author's presumption, to compare the growth velocity of schoolboys from middle school $1^{\text {st }}$ graders, 12 years of age to high school seniors, 17 years of age in the two countries over the little, longer period, from 1980 to 2017. High school seniors in 1980 were born in 1963, and middle school $1^{\text {st }}$ graders in 1975. Upper left of Korean line, $24.2 \mathrm{~cm}$ represents the growth in height of middle school $1^{\text {st }}$ graders in 1975 to high school seniors in 1980.

When minor fluctuations ignored, Korean schoolboys grew by $2.0-2.5 \mathrm{~cm}$ faster than their Japanese peers in velocity from 1 grade in middle school to senior grade in high school for more than two decades from 1980 to the early-2000s. The growth velocity in adolescence from 12 to 17 years of age was highest in the same year, 1980 in the two countries, $24.2 \mathrm{~cm}$ for South Korean boys and $21.0 \mathrm{~cm}$ for Japanese boys, respectively. The striking difference between the two countries is that the growth velocity fell mildly 
from $21.0 \mathrm{~cm}$ in 1980 to $18.0 \mathrm{~cm}$ in 2004 and then leveled off afterwards in Japan, whereas the velocity fell drastically from $24 \mathrm{~cm}$ in the first-1980s to $15.2 \mathrm{~cm}$ in 2012 and levelled off afterward in South Korea. The Korean boys grew nearly $3 \mathrm{~cm}$ slower in adolescence than their Japanese peers in the mid-2010s. When high school seniors are compared in the final survey year of 2017, South Korean boys were $173.5 \mathrm{~cm}, 3.0 \mathrm{~cm}$ taller than their Japanese peers, as repeatedly mentioned.

C) The author realized the biological fact that one year-old in1990 aged to 6 years old in 1995, and 17 years old in 2006 in turn.

\section{Changes in stature as net measures of inputs to health}

Teens in Japan were $2-3 \mathrm{~cm}$ taller than their Korean peers in the 1960-70s, when per capita consumption of animal products in Japan was significantly greater than in Korea, as mentioned earlier (table 3). Children in Japan ceased to grow any taller at all ages in the early-1990s, whereas children in Korea kept growing taller vigorously at all ages in the 1980-90s and teens in Korea outgrew their Japanese peers by $3.5 \mathrm{~cm}$ in the mid-2000s. In respect of consumption of animal products, Japan was twice as much as South Korea in terms of per capita caloric intakes from animal products $^{(\mathrm{D})}$ in 1990(1989-91average) and even 22\% grater in 2005, when Korean teens outgrew Japanese teens by $3 \mathrm{~cm}$, as remarked repeatedly.

Japanese children ceased to grow taller in height in the late1980s, when consumption of animal products was high and still increasing. Korean children ceased to grow taller in height in the mid-2000s, when per capita consumption of animal products was still increasing conspicuously (table 3). Matthias Blum states that "a high consumption of animal proteins alone does not result in increasing body heights if the overall consumption of other essential nutrients is insufficient" [19,21]. White Paper on Agriculture, 1994, Japan remarked a concern on wakamonononokudamaonbanare (steering a way from fruit by the young), without explicit implications on its outcomes [20]. Tanaka and Mori, 2003 and Mori and Stewart, 2013 endorsed the White Paper with refined statistical approaches, for the reliable cohort predictions [21,22]. The newer cohorts have continued to turn away from fruit in their at-home consumption. The newer generations in the latest decades in Japan have further reduced their fruit consumption (table 4).

On the basis of Household Income and Expenditures classified by age groups of household head, Statistics Korea [23], the author discovered that the newer generations in South Korea started to steer away from vegetables in at-home consumption in the early1990s and children in growing ages, 0 9, 10 14, 15 19 ate only $10 \%$ of vegetables as those older cohorts in their 50s in the end of the 2010s (table 4). Children in Japan ceased to grow taller in the late-1980s and their Korean peers also ceased to grow taller in the early-2000s. Children in growing ages in Japan started to turn away from fruit in the end of 1970s and those in South Korea started to steer away from vegetables in the early-1990s. With little background in nutritional sciences, the author has been presuming intuitively that fruit/vegetables may contain essential nutrients for child height growth. Casually observing students at universitycafeterias both in Japan and South Korea since the mid-1990s through the mid-2010s, the author had conceived that students in South Korea ate much more vegetables, mostly in the form of Kimchi, than their Japanese peers, some of whom take small pieces of tsukemono, pickles. The young in Japan do not care for fruits and also vegetables [24], (tables 4,5).

Table 4: Changes in per capita household expenditures by age groups, 1990 to 2019.

\begin{tabular}{|c|c|c|c|c|c|c|c|}
\hline \multicolumn{5}{|c|}{ A. vegetables } & \multicolumn{3}{|c|}{ (\% of the 50's) } \\
\hline Age Group & $1990-91$ & 1995-96 & 2000-01 & 2005-06 & 2010-11 & 2014-15 & 2017-19 \\
\hline $0-9$ & 49.8 & 31.4 & 30.5 & 19.4 & 12.6 & 13.6 & 8.5 \\
\hline $10 \sim 14$ & 51.8 & 34.5 & 34.1 & 22.5 & 15.3 & 15.1 & 10.1 \\
\hline $15 \sim 19$ & 51.6 & 35.1 & 36.5 & 25.9 & 18.9 & 16.8 & 12.9 \\
\hline $20 \sim 29$ & 55.2 & 42.1 & 43.8 & 34.5 & 27.7 & 25.5 & 22.4 \\
\hline $30 \sim 39$ & 73.3 & 64.7 & 62.3 & 54.0 & 48.2 & 50.2 & 45.6 \\
\hline $40 \sim 49$ & 96.0 & 87.8 & 85.5 & 78.0 & 72.6 & 73.3 & 68.1 \\
\hline $50 \sim 59$ & 100.0 & 100.0 & 100.0 & 100.0 & 100.0 & 100.0 & 100.0 \\
\hline $60 \sim$ & 95.1 & 98.3 & 104.0 & 107.0 & 116.2 & 121.1 & 130.5 \\
\hline per capita & \multicolumn{7}{|c|}{ (kg/year) } \\
\hline supply & 131.7 & 156.4 & 154.5 & 149.7 & 143.4 & 145.6 & 142.5 \\
\hline
\end{tabular}

Sources: Derived in current won from $\mathrm{Kr}$ Household Expenditure Surveys by Mori by means of the TMI model.

$\mathrm{KREI}$, Food Balance Sheet various issues, for per capita supply. 
Table 5: Per capita expenditures on dairies by age groups of household members by age groups, S. Korea, 1990 to 2015 (in 2015 Won).

\begin{tabular}{|c|c|c|c|c|c|c|}
\hline age/year & 1990-91 & 1995-96 & 2000-01 & 2005-06 & 2010-11 & $2015-16$ \\
\hline $0-9$ & 13798 & 17126 & 15798 & 14858 & 14935 & 12464 \\
\hline $10-14$ & 11290 & 13342 & 12077 & 12033 & 12554 & 10809 \\
\hline $15-19$ & 9386 & 10326 & 9807 & 10714 & 11247 & 9376 \\
\hline $20-29$ & 10386 & 12494 & 12701 & 12955 & 12569 & 9785 \\
\hline $30-39$ & 10616 & 13412 & 13727 & 13397 & 13694 & 12369 \\
\hline $40-49$ & 8519 & 8474 & 8606 & 8170 & 8355 & 10048 \\
\hline $50-59$ & 6831 & 6943 & 6968 & 7031 & 6751 & 8993 \\
\hline $60-69$ & 6948 & 6102 & 7203 & 7197 & 6800 & 9155 \\
\hline Av supply of milk & \multicolumn{6}{|c|}{ (kg/cap) } \\
\hline & 31.8 & 38.5 & 49.3 & 54.0 & 57.0 & 63.6 \\
\hline
\end{tabular}

Nationwide school lunch programs were launched in South Korea for all primary schools in the late 1990s and for middle schools and high schools in the early 2000s [25]. Japan started school lunch programs in the 1950s. In both countries, milk has been the key element of their school lunch feeding. Korea's Household Expenditures Surveys publish expenditures on "dairy", without further classifications, fluid milk, yoghurt, butter, cheese, etc. like in Japan's Family Income and Expenditure Surveys [26]. Assuming that fluid milk should account for the major expenditures for "dairy", household expenditures on "dairy" have been decomposed into expenditures by individual household members by age groups (table 5). In sharp contrast with vegetables, children in South Korea consume substantially more milk than older adults in their 40 s and 50s. Statistically, there are no signs to show that Korean children have been steering away from milk at home consumption in the past decades as is the case with vegetables.

D) The term used in Food Balance Sheets, FAOSTAT.

\section{Brief Conclusions}

In the past half century, Japan and South Korea made steady economic progress, accompanied by remarkable improvements in standard of living. Teens in Japan ceased to grow taller in the end of the 1980s and teens in Korea kept growing taller to overtake

\section{Appendix}

Appendix Table 1: Changes in BMI, schoolboys by age, S. Korea and Japan, 1970 to 2017.

\begin{tabular}{|c|c|c|c|c|c|c|c|c|c|}
\hline \multicolumn{10}{|c|}{ S. Korea } \\
\hline Boys_age & $(\mathrm{cm})$ & $(\mathrm{kg})$ & 1970 & $(\mathrm{~cm})$ & $(\mathrm{kg})$ & 1980 & $(\mathrm{~cm})$ & $(\mathrm{kg})$ & 1990 \\
\hline & height & weight & BMI & height & weight & BMI & height & weight & BMI \\
\hline 6 & 112.9 & 19.3 & 15.3 & 116.8 & 20.6 & 15.5 & 118 & 21 & 15.4 \\
\hline 12 & 143.7 & 36.7 & 17.8 & 146.6 & 36.8 & 17.3 & 150 & 41 & 18.3 \\
\hline 17 & 165.9 & 56.6 & 20.5 & 168.9 & 58.6 & 20.7 & 170 & 61 & 21.2 \\
\hline Boys_Age & $(\mathrm{cm})$ & $(\mathrm{kg})$ & 2000 & $(\mathrm{~cm})$ & $(\mathrm{kg})$ & 2010 & $(\mathrm{~cm})$ & $(\mathrm{kg})$ & 2017 \\
\hline & height & weight & BMI & height & weight & BMI & height & weight & BMI \\
\hline
\end{tabular}




\begin{tabular}{|c|c|c|c|c|c|c|c|c|c|}
\hline 6 & 120.1 & 23.3 & 16.2 & 121.8 & 24.9 & 16.7 & 120.4 & 24.2 & 16.7 \\
\hline 12 & 154.9 & 47.4 & 19.8 & 157.9 & 51.7 & 20.7 & 157.3 & 52.2 & 21.1 \\
\hline 17 & 173 & 65.3 & 21.8 & 173.7 & 68.1 & 22.6 & 173.7 & 71.1 & 23.4 \\
\hline \multicolumn{10}{|c|}{ Japan } \\
\hline \multirow[t]{2}{*}{ boys_age } & $(\mathrm{cm})$ & $(\mathrm{kg})$ & 1970 & $(\mathrm{~cm})$ & $(\mathrm{kg})$ & 1980 & $(\mathrm{~cm})$ & $(\mathrm{kg})$ & 1990 \\
\hline & height & weight & BMI & height & weight & BMI & height & weight & BMI \\
\hline 6 & 114.2 & 20.6 & 15.8 & 115.8 & 20.8 & 15.5 & 116.8 & 21.5 & 15.8 \\
\hline 12 & 146.5 & 38.1 & 17.8 & 149.8 & 41.4 & 18.5 & 151.4 & 43.5 & 19 \\
\hline 17 & 167.6 & 58.1 & 20.7 & 169.7 & 60.6 & 21 & 170.4 & 62 & 21.4 \\
\hline \multirow[t]{2}{*}{ boys_age } & $(\mathrm{cm})$ & $(\mathrm{kg})$ & 2000 & $(\mathrm{~cm})$ & $(\mathrm{kg})$ & 2010 & $(\mathrm{~cm})$ & $(\mathrm{kg})$ & 2017 \\
\hline & height & weight & BMI & height & weight & BMI & height & weight & BMI \\
\hline 6 & 116.7 & 19.2 & 14.1 & 116.7 & 21.4 & 15.7 & 116.5 & 21.4 & 15.8 \\
\hline 12 & 152.9 & 45.4 & 19.4 & 152.4 & 44.1 & 19 & 152.7 & 44 & 18.9 \\
\hline 17 & 170.8 & 62.6 & 21.5 & 170.7 & 63.1 & 21.7 & 170.6 & 62.6 & 21.5 \\
\hline
\end{tabular}

Sources: Calculated by the author, using School Health Survey data.

\section{References}

1. Steckel RH (1995) Statue and the Standard of Living. Journal of Economic Literature 33(4): 1903-1940.

2. Mori, Hiroshi (2018) Secular changes in child height in Japan and South Korea: Consumption of animal proteins and 'essential nutrients', Food and Nutrition Sciences 9(12): 1458-1471.

3. Mori, Hiroshi, Sanghyo K (2020) Child height and food consumption in Japan in the past century in comparison with South Korea: Animal protein and other essential nutrients. Global J Medical ResearchVersion 20(1): 1-8.

4. Mori, Hiroshi (2020) Secular changes in boys' height in South Korea: comparison with Japan. particularly with respect to growth velocity. J Food Nutr 4(6): 1-7.

5. Cole TJ (2012) The development of growth references and growth charts. Annals of Human Biology 39(5): 382-394.

6. Deaton A (2007) Height, health, and development. PNAS 104(33): 13232-13237.

7. Prentice A, Ward K, Goldberg C, Jarjou L, Moor S, et al. (2013) Critical windows for nutritional interventions against stunting. Am J Clin Nutr. 97(5): 911-918.

8. Cole T, Hiroshi M (2017) Fifty years of child height in Japan and South Korea: Contrasting secular trend patterns analyzed by SITAR, American J Human Biology 30(1): e23054.

9. Japanese government, Ministry of Health and Welfare, National Nutrition Survey, on the internet.

10. Republic of Korea, Korea Center for Disease Control and Prevention. Korea National Health and Nutrition Examination Survey (KNHANES).

11. Japanese government, Ministry of Education, School Health Examination Survey, various issues.

12. Republic of Korea, Department of Education, Center for Educational Statistics, Statistical Yearbook of Education, various issues. 9(12): 1.

13. FAO of the United Nations. FAOSTAT, Food Balance Sheets, by country and year. online.

14. Japanese government, Ministry of Agriculture, Food Balance Sheets, various issues.

15. Republic Korea government, KREI, Food Balance Sheets, various issues.

16. Mori H (2020) Comparative analysis of height growth velocities of school boys in South Korea and Japan in the past 50 years, Food and Nutrition Sciences 11(7): 859-868.
17. (2020) Secular changes in boys' height in South Korea, comparison with Japan, particularly respect to growth velocity. J Food Nutr 6: 1-7.

18. Gao P, Erick S (2020) The growth pattern of British children, 1850 to 1975, The Economic History Review: 1-31.

19. Blum M (2013) Cultural and genetic influences on the biological standard of living'. Historical Method 46(1): 19-30.

20. (1994) Japanese government, Ministry of Agriculture, Forestry and Fisheries (1995) White Paper on Agriculture Tokyo.

21. Tanaka M, Mori H (2003) How will consumption of fresh fruit change in a rapidly aging society of Japan, Agriculture and Horticulture 78(8): 845-850

22. Mori H, Stewart H (2011) Cohort analysis: Ability to predict future consumption-The case of fresh fruit in Japan and rice in Korea, Annual Bulletin of Social Science, Senshu University 45: 153-173.

23. (1990) Republic of Korea, Statistics Korea, Household Income and Expenditure Survey.

24. Mori H (2019) Why did Japanese children cease to grow taller in height in the midst of a booming economy in contrast with South Korean youth? Annual Bulletin of Social Science Senshu University (53): 223-240.

25. Dewa T (2013) School lunch programs in practice in South Korea. Ryukoku University Review 481: 26-45 (in Japanese).

26. Japanese government, Bureau of Statistics, Family Income and Expenditure Survey.various issues.

27. Mori H, Lowe E, Everett G, Dennis L, Clason, et al. (2000) Cohort analysis of food consumption: A case of rapidly changing Japanese consumption. IFAMR 3(2): 189-205.

28. Gustavsen GW, Rickertsen K (2013) Consumer cohorts and purchases of non-alcoholic beverages. Empirical Economics.

29. Mori H, Inaba T, Dyck J (2016) Accounting for structural changes in demand for foods in the presence of age and cohort effects: the case of fresh fish in Japan. Evolut Inst Econ 13(2): 363: 379.

30. Tanaka M, Mori H, Inaba T (2004) "Re-estimating per capita individual consumption by age from household data." Japanese J Rural Economics 6: 1-11.

31. Mori H (2020) Structural changes in food consumption and human height in East Asia, LAMBERT Academic Publishing. Berlin: 1-156. 